\title{
Lead Toxicity, Adsorption and Resistance in Chlorella Sp.
}

\author{
Pawan Raj Shakya $^{1^{*}}$ and Neena Khwaounjoo (Malla) ${ }^{2}$ \\ ${ }^{1}$ Department of Chemistry, Padma Kanya Multiple Campus, Tribhuvan University, Bagbazaar, \\ Kathmandu \\ ${ }^{2}$ Department of Botany, Padma Kanya Multiple Campus, Tribhuvan University, Bagbazar, Kathmandu \\ *E-mail: pawansh2003@yahoo.com
}

\begin{abstract}
These days, unicellular green microalgae have been widely used for removal of toxic heavy metals from contaminated soil and water bodies. In the present investigation, a lead resistant PbR-11 strain isolated from Chlorella sp. by EMS mutagenesis was compared against the wild type (WT) of the same species for $\mathrm{Pb}^{2+}$ accumulating capacity. Growth of both the tested algal cells, PbR-11 and WT (control) were found to be retarded with increasing $\mathrm{Pb}^{2+}$ concentrations in the medium. However, higher $\mathrm{ID}_{50}$ value of the $\mathrm{PbR}-11$ exhibited some degree of resistance to the metal toxicity. When exposed to the liquid medium containing $50 \mu \mathrm{M} \mathrm{Pb}^{2+}$, kinetic experiments showed rapid removal and adsorption of the metal ions in both the algal cells during the first few hours. Compared to WT, the PbR-11 showed significantly higher percentage removal and adsorption of $\mathrm{Pb}^{2+}$ at 15 minutes and 48 hours interval of time respectively. Extracellular $\mathrm{Pb}^{2+}$ adsorption was found significantly higher than intracellular uptake in the tested algal cells although both the processes occurred simultaneously. Total $\mathrm{Pb}^{2+}$ accumulation and distribution between the external and internal cell fractions of the PbR-11 were significantly higher to that of the WT. Thus, the strain appeared more useful for remediation of contaminated sites.
\end{abstract}

Key words: EMS mutagenesis, heavy metals, Chlorella sp., adsorption, lead toxicity

\section{Introduction}

Release of toxic metal pollutants in the environment has increased enormously over the past several decades as a result of anthropogenic activities (Ajmal and Khan, 1985). Among the metal pollutants, lead has become a serious worldwide environmental problem since its toxic effect to human and environment has been well recognized (U.S. ATSDR, 2005). The metal is toxic even at very low exposure levels (Fernando et al., 1981). Important releases of lead are from natural as well as anthropogenic sources. Natural releases of lead are from the natural mobilization of naturally occurring lead from the Earth's crust and mantle, such as volcanic activity and the weathering of rocks. Anthropogenic releases of lead are from mining and processing activities, manufacturing, use, disposal, recycling and reclamation; incineration and installations for municipal waste, open burning and emissions from leaded petrol (Harrison and Laxen, 1980).

In human, neurological, cardiovascular, renal, gastrointestinal, haematological and reproductive effects are due to lead toxicity (U.S. ATSDR, 2005). Lead is accumulated in bone and may serve as a source of exposure later in life. Organo-lead compounds, such as tri-alkyl-lead and tetraalkyl-lead compounds, are more toxic than inorganic forms of lead (Corrin and Natusch, 1977). In the environment, lead is toxic to plants, animals and microorganisms (Fernando, 1995). It bioaccumulates in most organisms. In surface 
waters, residence times of biological particles containing lead have been estimated at up to two years (Corrin and Natusch, 1977). Although lead is not very mobile in soil, lead may enter surface waters as a result of the erosion of lead-containing soil particles and the dumping of waste containing lead products.

Heavy metals like lead, cadmium, mercury etc., cannot be degraded or destroyed by biological or chemical means unlike many other organic toxic pollutants; however rendering toxic forms into less toxic or harmless is the only way to bring about the metal detoxification. Many conventional physico-chemical methods such as excavation, precipitation with lime, adsorption, flocculation, filtration etc., are costly and inefficient for remediation of toxic metals from contaminated sites (Kamnev and Van der Lelie, 2000). Therefore, there is a growing realization to clean up the metal contaminated soil and water bodies using microorganisms, algae or plants since they are cost effective, efficient and eco-friendly in nature (Salt et al., 1998).

Algae are capable of accumulating heavy metals to concentrations several orders of magnitudes higher than in the surrounding medium (Beker, 1986) and have therefore been used for their removal from contaminated sites (Sandau et al., 1996; Vilchez et al., 1997). Their high accumulating potential can even be used for the enrichment, recovery or recycling of traces of valuable metals like uranium, gold and silver from nature (Borowitzka and Borowitzka, 1988; Lopez-Suarez et al., 2000; Kessler 1986). Many algae growing in metal-polluted environments display an ability to tolerate high concentrations of toxic metals (De Filippis and Pallaghy,1994). Different groups of algae exhibit varying levels of tolerance to heavy metals.

Literature reveal that different Chlorella species have been isolated from highly polluted domestic, industrial and metal contaminated lakes (Lopez-Suarez et al., 2000; Kessler, 1986; Kaplan et al., 1995; Wong et al., 2000). Many studies have been addressed on metal detoxification of various Chlorella spp.; however little information is available regarding the lead toxicity and resistance mechanisms in Chlorella sp. Therefore, a unicellular green microalga, Chlorella sp. has been used in the present investigation since it resembles all characteristics to that of the common algal groups. The species is abundant in wastewater and surface water bodies and may be used as a model organism to study metabolic processes in photosynthetic eukaryotic higher plants because of its similarity. Hence, the present study is an attempt to isolate lead resistant Chlorella strains from the wild type (WT) culture and then characterize the mechanism(s) confirming resistance to lead toxicity.

\section{Materials and methods \\ Growth conditions}

Lead resistant strains from the wild type Chlorella sp. were isolated by EMS (Ethylmethane Sulphonate) mutagenesis using the Herskowitz Lab Protocol (Sil and Chenevert, 1998). So far, fifty five-lead resistant strains (those survived and grew only) were isolated from the procedure described. The EMS mutagenized strains were designated as $P b R$ with numerals. All the strains were maintained in modified BG11 liquid mineral medium containing $25 \mu \mathrm{M}$ $\mathrm{Pb}^{2+}$. The cultures were continuously exposed to a light intensity of 20-50 $\mu \mathrm{mol}$ by cool white fluorescent lamps while 
Pawan Raj Shakya and Neena Khwaounjoo (Malla) / Our Nature (2012) 10: 156-166

incubated in a gyratory shaker (180 rev./min) at $27^{\circ} \mathrm{C}$. A $250 \mathrm{ml}$ capacity Erlenmeyer flask containing a volume of $100 \mathrm{ml}$ of the liquid medium was used for performing all experiments. Samples were periodically removed from the flasks to monitor growth of the algal cells. When the cultures reached the stationary phase of growth, they were further inoculated into fresh liquid medium to keep growing unless otherwise mentioned. One of the fifty five lead resistant strains, PbR-11 was selected for the present investigation.

\section{Preparation of stock metal solution}

Stock solution $(0.1 \mathrm{M})$ of lead salt was prepared by dissolving the calculated amount of $\mathrm{Pb}\left(\mathrm{NO}_{3}\right)_{2}$ in ultra pure water and filter sterilized. The solution was divided into 4-ml aliquots and stored frozen at minus $20^{\circ} \mathrm{C}$. The metal solution was defrosted and used when required.

\section{Calibration of absorbance (optical density) vs. cell numbers}

Growth of the cultures was monitored by measuring absorbance (optical density) in Spectrophotometer at $540 \mathrm{~nm}$ or counting cell numbers by a Hemacytometer. Initially, the absorbance was calibrated against the cell numbers. The calibration was done with a purpose of calculating cell numbers from the absorbance or vice versa as necessary.

\section{Growth experiments}

Cultures of the selected PbR-11 and Chlorella sp. (WT) at the exponential phase of growth were used to study growth pattern in presence of lead. Erlenmeyers each containing $100 \mathrm{ml}$ of BG-11 medium were firstly sterilized in autoclave and then cooled at room temperature keeping inside the laminar flow hood so as to avoid any kind of contamination. The stock lead solution was added to the autoclaved medium in calculated amount such that they were at concentrations of $0,1,10,50$ and $100 \mu \mathrm{M}$ respectively. The cultures were then inoculated to the medium in such a way that the initial cell densities were in the range of $5.0-5.5 \times 10^{5}$ cells $/ \mathrm{ml}$ of the liquid medium. The algal growth was monitored by measuring the change in absorbance of the algal cells at $540 \mathrm{~nm}$. The measurement was taken at the time of inoculation and each day thereafter until it reached the stationary phase. Cells were also counted using a Hemacytometer. The growth rate of the algal cultures was determined between the 2 nd and the 6th days by the following equation:

$$
\mu=\left(\ln \mathrm{X}_{6}-\ln \mathrm{X}_{2}\right) /\left(\mathrm{T}_{6}-\mathrm{T}_{2}\right)
$$

Where $\mu$ is the specific growth rate of the algal culture, $X_{6}$ is the $A_{540 \mathrm{~nm}}$ of the algal culture at time $T_{6}$, and $X_{2}$ is the $A_{540 \mathrm{~nm}}$ of the algal culture at time $\mathrm{T}_{2}$ (Ajmal and Khan, 1985). All the experiments were carried out in triplicate.

\section{Kinetic experiments on adsorption of $\mathrm{Pb}^{2+}$ by the WT and PbR-11 cultures}

Firstly, the selected lead resistant strain, PbR-11 initially maintained in the medium containing $25 \mu \mathrm{M} \mathrm{Pb}^{2+}$ was inoculated into the fresh liquid medium without lead and allowing them to grow for 5 days. The process was repeated three times to ensure that the cells were completely free from the metal ions. Then, the PbR-11 cells at the stationary phase of growth were collected by centrifugation $\left(10^{\circ} \mathrm{C}, 8000 \mathrm{~g}\right.$ for $\left.15 \mathrm{~min}\right)$. The pelleted cells were re-suspended in 10 $\mathrm{ml}$ of fresh liquid medium and counted in the Hemacytometer to note the actual cell 
Pawan Raj Shakya and Neena Khwaounjoo (Malla) / Our Nature (2012) 10: 156-166

numbers. Three flasks containing fresh liquid medium were inoculated with the dense cell suspension such that each flask contained $10^{9}$ cells per hundred milliliters. The WT culture was also used as control in parallel.

To study the adsorption kinetics at different time intervals, the metal solution was added to each of the flasks maintaining a final concentration of $50 \mu \mathrm{M}$. From each of the metal added flasks, a $10-\mathrm{ml}$ sample was drawn immediately in order to represent a zero hour sampling, however it took 15 minutes to proceed through a complete treatment. Hence, the 15 minutes was regarded as the zero hour samples. In a similar way, the samples were drawn at $1 / 2$, $1,2,4,8,12,24$ and 48 hours respectively. The flasks were placed back to the shaker after each sample drawn. The samples, at each of these time intervals were spun down in a bench centrifuge $(3500 \mathrm{rpm}, 10 \mathrm{~min})$ and the supernatants collected separately for metal analysis. This supernatant yields the residual metal left over the medium. The cell pellets were then washed with $5-\mathrm{ml}$ of EDTA (10 g/lit.) three times (Roy et al., 1993). Each time, the cells were spun down (3500 rpm, $10 \mathrm{~min}$ ) and the supernatants containing EDTA were collected for metal analysis. The experiment was carried out in triplicate. This analysis yields the concentration of $\mathrm{Pb}^{2+}$ adsorbed to the cell surface at varying time intervals.

\section{Sample digestion and preparation for lead determination}

The cell pellets after EDTA treatment were finally subjected to the experiments involving the intracellular $\mathrm{Pb}^{2+}$ uptake. For this, each cell pellet samples were resuspended in $10 \mathrm{ml}$ of double distilled water by gentle vortex. The cells were spun down and re-suspended in distilled water repeatedly for three times following the process of washing. Each of the washed cells was then re-suspended in $1 \mathrm{ml}$ of double distilled water and transferred to digestion tubes. The cell suspensions in the digestion tubes were treated with $2 \mathrm{ml}$ of conc. nitric acid. The mixture was placed in a chemical hood overnight so as to ensure a complete dissolution and prevent foaming during subsequent digestion processes. The sample was digested at $100^{\circ} \mathrm{C}$ for 1 hour followed by gradually increasing the temperature up to $230^{\circ} \mathrm{C}$ (Foster, 1982). The digestion was carried out for approximately $3 \mathrm{~h}$ until the solution became completely clear and transparent. After the digestion was completed, the digest was cooled, diluted and adjusted to a final volume of 5 $\mathrm{ml}$ with double distilled water. Then, the metal was determined using a Perkin Elmer $1100 \mathrm{~B}$ atomic absorption spectrophotometer. This analysis reveals the total lead accumulated inside the cells at different time intervals i.e., intracellular lead uptake or absorption.

\section{Presentation of the data}

Each experiment was conducted in triplicate and the mean values were presented with their standard deviations. The data were subjected to student's T-tests at 95\% level of confidence or at $5 \%$ level of significance.

\section{Results \\ Effect of $P b^{2+}$ on growth of the WT and PbR-11}

The effect of increasing $\mathrm{Pb}^{2+}$ concentration on growth of the WT and PbR-11 is given in table 1. Under the same experimental condition, the presence of $1 \mu \mathrm{M} \mathrm{Pb}^{2+}$ had no effect on growth rate of the WT and PbR-11 
while growth inhibition of the algal cells was observed by $36 \%$ and $25 \%$ respectively in presence of $10 \mu \mathrm{M} \mathrm{Pb}^{2+}$. Similarly, the PbR-11 sustained less inhibitory effect (56\%) compared to that of the WT $(80 \%)$ in the presence of $50 \mu \mathrm{M} \mathrm{Pb}^{2+}$. The presence of $100 \mu \mathrm{M} \mathrm{Pb}^{2+}$ had significantly arrested the growth rate of both the algal cells. Under the condition, the PbR-11 sustained inhibitory effect by $90 \%$ while the WT was by $96 \%$. This shows that the PbR-11 could survive to some extent even at higher $\mathrm{Pb}^{2+}$ concentration compared to the WT. Based on the growth rates, inhibition of 50\% growth rate $\left(\mathrm{ID}_{50}\right)$ was also calculated on the basis of the growth rates. The $\mathrm{ID}_{50}$ was obtained as: PbR-11 $(34 \mu \mathrm{M})$ and WT (20 $\mu \mathrm{M})$. Thus, higher $\mathrm{ID}_{50}$ value of the PbR-11 compared to the WT indicated a certain degree of resistance to $\mathrm{Pb}^{2+}$.

Table 1. Percentage growth rate of WT and PbR-11 at different $\mathrm{Pb}^{2+}$ concentration

\begin{tabular}{|c|c|c|c|c|c|}
\hline \multirow[b]{2}{*}{ Strain } & \multicolumn{5}{|c|}{$\mathbf{P b}^{2+}$ concentration $(\mu \mathrm{M})$} \\
\hline & $\begin{array}{l}\mathbf{0} \\
\text { (control) }\end{array}$ & 1 & 10 & 50 & 100 \\
\hline WT & 100 & 94 & 64 & 20 & 4 \\
\hline PbR-11 & 100 & 96 & 75 & 44 & 10 \\
\hline
\end{tabular}

\section{Cell counts of the WT and PbR-11}

Table 2 shows the initial and final cell counts of the WT and PbR-11 in the liquid growth medium. Both the cultures were exposed to the medium containing $50 \mu \mathrm{M}$ $\mathrm{Pb}^{2+}$ up to 48 treatment hours. The final cell numbers of both the cultures even after their exposure to 48 hours in $50 \mu \mathrm{M} \mathrm{Pb}^{2+}$ did not show significantly different compared to that of the initial cell counting. Besides, the difference of initial and final (48 hours of treatment with $\mathrm{Pb}^{2+}$ ) cell counting between the tested cell lines was not found significant (t-test, $\mathrm{p}>0.05$ ). Therefore, the same cell numbers were presumed for all time intervals throughout the kinetic experiment and for further calculations as well.

Table 2. Cell numbers per $100 \mathrm{ml}$ of liquid growth medium at initial (before addition of $\mathrm{Pb}$ ) and final (48 hours after addition of $\mathrm{Pb}$ ) hours of treatment; the WT and $\mathrm{PbR}-11$ were treated with $50 \mu \mathrm{M} \mathrm{Pb}^{2+}$

\begin{tabular}{llc}
\hline \multirow{2}{*}{ Strain } & \multicolumn{2}{c}{$\begin{array}{c}\text { Cell numbers per 100 ml of growth } \\
\text { medium }\end{array}$} \\
\cline { 2 - 3 } & Initial & Final \\
& & $6.3 \times 10^{9}$ \\
WT & $6.1 \times 10^{9}$ & $7.7 \times 10^{9}$ \\
PbR-11 & $7.0 \times 10^{9}$ &
\end{tabular}

\section{Kinetics of $\mathrm{Pb}^{2+}$ removal and adsorption from the growth medium by WT}

Figure 1 (A and B) shows the kinetics of $\mathrm{Pb}^{2+}$ extracellular adsorption and removal by the WT. On exposure to $50 \mu \mathrm{M} \mathrm{Pb}^{2+}$, the rate of the metal ion removal was rapid during the first few hours, increased gradually until 12 hours and then reached a steady state thereafter (Fig. 1B). Decreasing residual $\mathrm{Pb}^{2+}$ concentration in the medium with time indicated the amount of $\mathrm{Pb}^{2+}$ being removed from the medium simultaneously (Fig. 1A). During the first hour of treatment, $\mathrm{Pb}^{2+}$ removal from the medium was $44 \%$ (Fig. 1B). Correspondingly, extracellular adsorption of $\mathrm{Pb}^{2+}$ occurred side by side, being rapid in the first half-hour and then remained unaltered until 2 hours (Fig. 1A). Lead adsorbed by the WT cell surfaces during the first hour was $36 \%$. Further, a gradual increase in $\mathrm{Pb}^{2+}$ adsorption was observed until 12 hours and then reached the equilibrium point after this treatment hour. Initially, the removal of $\mathrm{Pb}^{2+}$ 
Pawan Raj Shakya and Neena Khwaounjoo (Malla) / Our Nature (2012) 10: 156-166

from the medium was $26 \%$ at 15 minutes. Finally $71 \%$ of the total lead supplemented was found to be removed at 48 hours of which $54 \%$ was externally bound to the cell walls.
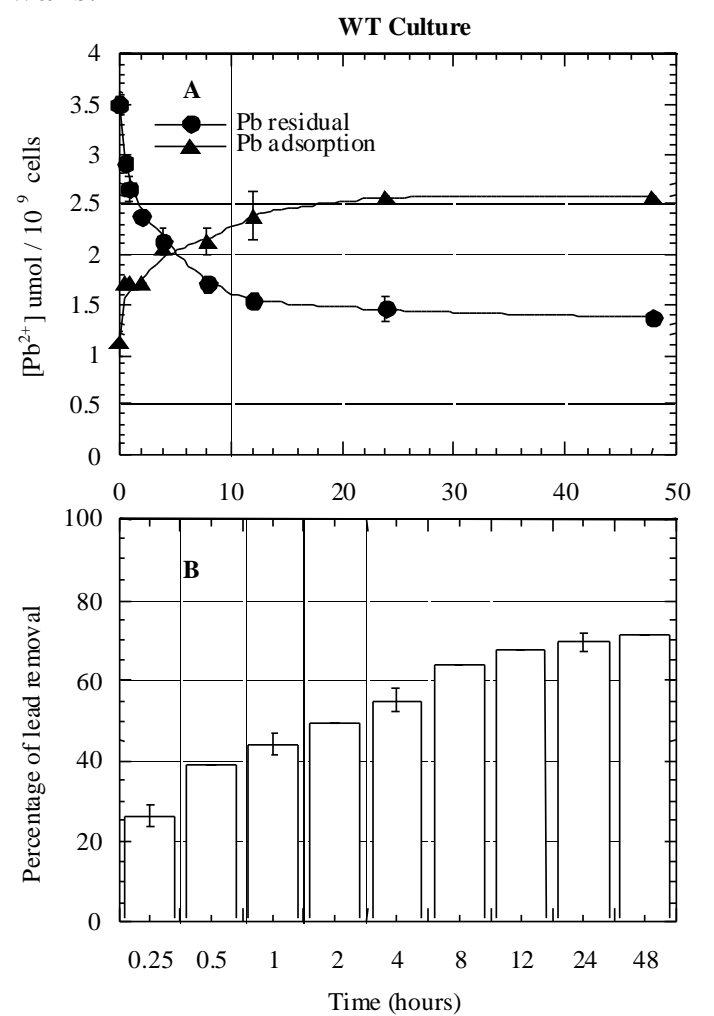

Figure 1. Extracellular adsorption and residual concentration of $\mathrm{Pb}^{2+}$ at different time intervals $(\mathrm{A})$ and percentage removal of $\mathrm{Pb}^{2+}$ from the medium (B) in WT culture; mean (standard deviation; $n=3$ )

Total lead accumulation and lead in external and internal cell fractions of WT

The WT showed a gradual accumulation of $\mathrm{Pb}^{2+}$ with increasing time of exposure to the medium containing $50 \mu \mathrm{M} \mathrm{Pb}^{2+}$ (Tab. 3). Total $\mathrm{Pb}^{2+}$ accumulation reached a steady state after about 12 hours while the accumulation was rapid during the first few hours. The distribution of $\mathrm{Pb}^{2+}$ between the external and internal cell fractions also increased with duration of exposure indicating that the process of adsorption and absorption occurred simultaneously. The amount of $\mathrm{Pb}^{2+}$ associated with the external cell fractions was higher than the internal at each time interval. While the extracellular adsorption was found gradually increased, intracellular uptake appeared fluctuating at different time intervals although the tendency of $\mathrm{Pb}^{2+}$ association was of increasing order. Of the total $\mathrm{Pb}^{2+}$ accumulated $\left(3.38 \mu \mathrm{mol}\right.$ per $10^{9}$ cells $)$ at 48 hours, $76 \%$ was externally bound to the cell surface whereas only $24 \%$ was found inside the cells.

Table 3. Total $\mathrm{Pb}^{2+}$ accumulation and distribution between external and internal cell fractions of the WT at different time intervals; mean (standard deviation; $n$ $=3$ )

\begin{tabular}{lllll}
\hline Strain & $\begin{array}{l}\text { Time } \\
\text { Int. } \\
\text { (hr. })\end{array}$ & \multicolumn{3}{l}{ Lead Association $\left(\mu \mathbf{m o l} / \mathbf{1 0}^{9}\right.$ cells $)$} \\
\cline { 3 - 5 } & & External & Internal & $\begin{array}{l}\text { Total } \mathbf{P b}^{2+} \\
\text { accumulated }\end{array}$ \\
\hline WT & 0.25 & 1.11 & 0.14 & $1.25(0.69)$ \\
& & $(0.10)$ & $(0.00)$ & \\
& 0.5 & 1.70 & 0.14 & $1.84(1.10)$ \\
& & $(0.00)$ & $(0.00)$ & \\
& 1.0 & 1.70 & 0.40 & $2.10(0.92)$ \\
& & $(0.00)$ & $(0.10)$ & \\
& 2.0 & 1.70 & 0.65 & $2.35(0.74)$ \\
& & $(0.00)$ & $(0.00)$ & \\
& 4.0 & 2.04 & 0.57 & $2.61(1.04)$ \\
& & $(0.00)$ & $(0.10)$ & \\
& 8.0 & 2.13 & 0.91 & $3.04(0.86)$ \\
& $(0.10)$ & $(0.10)$ & \\
& 12.0 & 2.39 & 0.82 & $3.21(1.11)$ \\
& $(0.25)$ & $(0.24)$ & \\
& 24.0 & 2.56 & 0.74 & $3.30(1.29)$ \\
& $(0.00)$ & $(0.10)$ & \\
& 48.0 & 2.56 & 0.82 & $3.38(1.22)$ \\
& $(0.00)$ & $(0.00)$ & \\
\hline
\end{tabular}

\section{Kinetics of $\mathrm{Pb}^{2+}$ removal and adsorption from the growth medium by PbR-11}

Apparently, PbR-11 exhibited a distinct kinetics of $\mathrm{Pb}^{2+}$ extracellular adsorption and 
removal (Figs. $2 \mathrm{~A}$ and $\mathrm{B}$ ) compared to the WT. On exposure to $50 \mu \mathrm{M} \mathrm{Pb}^{2+}$, the rate of
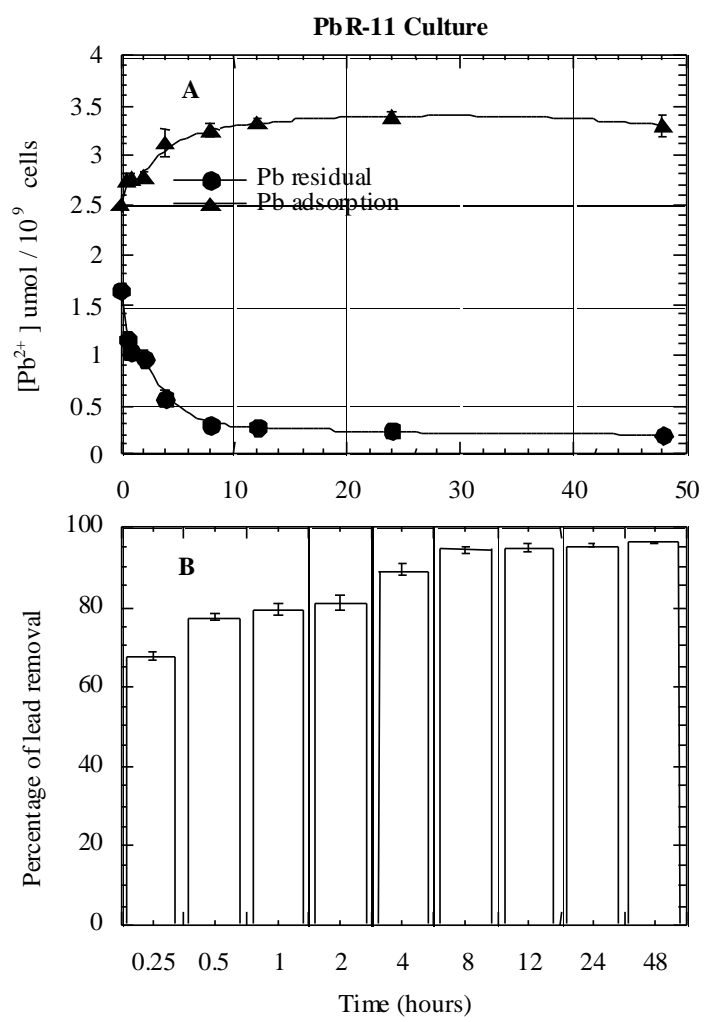

Figure 2. Extracellular adsorption and residual concentration of $\mathrm{Pb}^{2+}$ at different time intervals (A) and percentage removal of $\mathrm{Pb}^{2+}$ from the medium (B) in PbR-11 culture; mean (standard deviation; $n=3$ )

$\mathrm{Pb}^{2+}$ removal from the medium was very rapid during the first few hours unlike that of the WT. The removal was more than $80 \%$ within few hours. In other words, residual concentration of $\mathrm{Pb}^{2+}$ in the medium was less than $20 \%$ within the first few hours of treatment (Fig. 2A). Until 48 treatment hours, the strain showed $96 \%$ removal of the total metal ions from the medium (Fig. 2B). Correspondingly, a very rapid increase in the metal adsorption was found in the strain unlike the WT. The adsorption of $\mathrm{Pb}^{2+}$ to the cell surface was very rapid during the first few minutes, remained almost constant until 2 hours and gradually increased up to 8 hours (Fig. 2A). The adsorption attained a point of saturation after 8 hours. At 15 minutes, $\mathrm{Pb}^{2+}$ removal from the growth medium was $67 \%$ contributing $50 \%$ to the extracellular adsorption alone. This figure shows difference significantly to that of the WT in terms of $\mathrm{Pb}^{2+}$ removal and adsorption at 15 minutes. Similarly, of the $96 \% \mathrm{~Pb}^{2+}$ removal at 48 treatment hours, $66 \%$ was found externally adsorbed to the cell walls of the strain, which is higher to that of the WT.

Total lead accumulation and lead in external and internal cell fractions of PbR11

The PbR-11 demonstrated a higher accumulation of $\mathrm{Pb}^{2+}$ per $10^{9}$ cells compared

Table 4. Total $\mathrm{Pb}^{2+}$ accumulation and distribution between external and internal cell fractions of the PbR-11 at different time intervals; mean (standard deviation; $\mathrm{n}=3$ )

\begin{tabular}{lllll}
\hline Strain & $\begin{array}{l}\text { Time } \\
\text { Int. } \\
\text { (hr.) }\end{array}$ & \multicolumn{3}{l}{ Lead Association $\left(\mu \mathrm{mol} / \mathbf{1 0}^{9}\right.$ cells $)$} \\
\cline { 3 - 5 } & & External & Internal & $\begin{array}{l}\text { Total } \mathbf{P b}^{2+} \\
\text { accumulated }\end{array}$ \\
\hline PbR- & 0.25 & 2.50 & 0.85 & $3.35(1.10)$ \\
& & $(0.01)$ & $(0.01)$ & \\
& 0.5 & 2.75 & 1.15 & $3.90(0.97)$ \\
& & $(0.01)$ & $(0.00)$ & \\
& 1.0 & 2.80 & 1.30 & $4.10(0.85)$ \\
& & $(0.01)$ & $(0.01)$ & \\
& 2.0 & 2.81 & 1.31 & $4.10(0.85)$ \\
& & $(0.00)$ & $(0.01)$ & \\
& 4.0 & 3.10 & 1.46 & $4.56(1.10)$ \\
& & $(0.00)$ & $(0.01)$ & \\
& 8.0 & 3.30 & 1.47 & $4.77(1.20)$ \\
& $(0.10)$ & $(0.00)$ & \\
& 12.0 & 3.32 & 1.46 & $4.78(1.29)$ \\
& $(0.25)$ & $(0.10)$ & \\
& 24.0 & 3.34 & 1.44 & $4.78(1.34)$ \\
& $(0.00)$ & $(0.00)$ & \\
& 48.0 & 3.30 & 1.50 & $4.80(1.23)$ \\
& $(0.00)$ & $(0.10)$ & \\
\hline
\end{tabular}


Pawan Raj Shakya and Neena Khwaounjoo (Malla) / Our Nature (2012) 10: 156-166

to that of the WT (Tab. 4). Besides, the distribution of $\mathrm{Pb}^{2+}$ between the external and internal cell fractions of the strain was also higher to the WT. The strain accumulated almost all of the metal supplemented within the few hours showing a saturation point at early treatment hours. The lead in external and internal cell fractions increased with duration of exposure to the metal solution. But they were found to be saturated with the metal during the first few hours showing that the strain promptly responded to the lead toxicity. This further indicates that the strain demonstrated more resistance to the toxic metal ion by defending in terms of adsorption and absorption mechanisms. Of the total metal accumulated $\left(4.80 \mu \mathrm{mol} / 10^{9}\right.$ cells) by the strain at 48 hours, $69 \%$ and $31 \%$ of $\mathrm{Pb}^{2+}$ were externally bound and inside the cells respectively.

\section{Discussion}

The algal growth is affected by the presence of heavy metals and the inhibitory effect on the growth rate is more pronounced with increasing metal concentrations in the medium (Wong and Wong, 1990; Macfie and Welbourn, 2000). However, their resistance to the metal toxicity may vary with algal species (Jin et al., 1996b). The present study involving effects on growth rate of the WT and PbR-11 in presence of increasing $\mathrm{Ni}^{2+}$ concentrations (Tab. 1), agree well with their findings. Both the algal cells responded with inhibitory effects in order of increasing metal concentration but comparatively, the PbR-11 strain exhibited better growth rate (Tab. 1), which may plausibly be due to EMS mutagenesis. The $\mathrm{ID}_{50}$ value of the strain was also nearly double to that of the WT showing that the strain possesses some degree of resistance to the metal toxicity.
A variety of resistance mechanisms are exhibited by microalgae in response to metal toxicity. Possible mechanisms that govern heavy metal resistance are metal binding to the cell wall, reduced transport across the cell membrane, active efflux, compartmentalization and chelation (Prasad, 1995). In general, two mechanisms are taken into account for the removal of metal ions. One is metabolically independent passive surface adsorption or biosorption, while the other, active uptake of the metal ions into the cells, is metabolically dependent. Both mechanisms work simultaneously in algal cells in which adsorption is very rapid and occurs in few minutes as reported by several studies (Crist et al., 1988; Honeyman and Santschi, 1988; Wang and Wood, 1984). The present study is in agreement with the above findings. Results reveal that the rate of $\mathrm{Pb}^{2+}$ adsorption was very rapid during the first few minutes, i.e., 15 minutes in the present study and the process gradually reached a steady state after few hours of treatment in both the tested cells (Figs. 1 and 2). However, the difference in terms of adsorption patterns occurred between them although their initial cell counts were almost in the same range (Tab. 2). It is important to mention here that the kinetic experiment for extracellular adsorption at zero hour sampling required about 15 minutes to complete the process of treatment. Therefore, zero hour is regarded as 15 minutes or vice versa (Figs. 1 and 2). The result also shows that most of the metal ion was bound to the cell walls in the early 15 minutes of treatment. The rapid adsorption to the algal cell surface may be due to the availability of specific binding sites to which the metal ions are bound until all the sites are saturated followed by a slow 
intracellular uptake (Wang and Wood, 1984). Furthermore, the difference in the magnitude of metal binding capacity to the external cell fractions between the WT and $\mathrm{PbR}-11$ at different time intervals may be due to different affinities of the algal cells towards the metal ion (Hamdy, 2000).

Active intracellular uptake comes into play once metal ions are bound by the cell wall. The membrane potential, which is negative on the inside of the plasma membrane (Kramer et al.,1996), provides a strong driving force for the uptake of metal ions through secondary transporters. In the present study, the intracellular $\mathrm{Pb}^{2+}$ uptake in the tested cells was significantly less compared to the extracellular adsorption (Tabs. 3 and 4). It may be because of the reason that when the binding sites of the algal cells became exhausted or nearly saturated, the cells began taking up the metal ion by active physiological mechanisms (Prasad, 1995). Inside the cell, metals are chelated and excess metal is sequestered by transport into the vacuole exhibiting intracellular detoxification mechanisms. (Clemens et al., 2002). Mehta and Gaur (1999) noticed that the greater the toxicity of a metal, the greater is the intracellular concentration of proline in Chlorella vulgaris, which is induced to protect the alga from metal toxicity. A common response of organisms to metal toxicity is the synthesis of metallothioneins (Hamer, 1986) and phytochelatins (Kondo et al., 1984), which may play a role in the intracellular detoxification of metal ions. But the present study could not investigate the fate of $\mathrm{Pb}^{2+}$ inside the cells. However, the total $\mathrm{Pb}^{2+}$ accumulation and distribution of the same between the external and internal cell fractions show that both the processes occur simultaneously in response to the metal toxicity. Indeed, the PbR-11 strain showed significant accumulation and distribution of the metal ions compared to that of the WT indicating its better resistance capacity. It was also noted that $\mathrm{Pb}^{2+}$ bound to the external cell surface was significantly high (t-test, $\mathrm{p}>0.05)$ compared to that of the metal inside the cells in both the tested cells (Tabs. 3 and 4). However, the presence of other metal ions in the growth medium, light, temperature, time of exposure to metal ions and $\mathrm{pH}$ are some of the dependent and sensitive parameters of the processes (Donmez et al., 1999; Bajguz, 2000; Hamdy, 2000).

\section{Conclusion}

In conclusion, the PbR-11 strain possesses comparatively higher $\mathrm{Pb}^{2+}$ accumulating potential than the WT exhibiting a certain degree of resistance to the metal toxicity. The rapid removal of the metal followed by the simultaneous extracellular adsorption suggests that the strain plays important role in reducing the level of metal concentration from the medium. The findings also open wide prospects for further research regarding the nature and chemical compositions of the algal cell walls since the metal binding affinity also depends on the availability of various functional groups. Besides, the present study is also expected to provide baseline information regarding the status of metal contaminated soil and water bodies. The metal content in this alga can be a reflection of background concentrations of heavy metals contaminated in the sites. Moreover, a comprehensive understanding of physiological, biochemical and molecular mechanisms conferring $\mathrm{Pb}^{2+}$ resistance in Chlorella sp. would enable the engineering of metal accumulating organisms such that 
Pawan Raj Shakya and Neena Khwaounjoo (Malla) / Our Nature (2012) 10: 156-166

they could serve as a tool in water treatment, wastewater treatment and controlling the environment from toxic metal pollution.

\section{Acknowledgement}

One of the authors (P.R. Shakya) is thankful to Department of Environmental Resources, Technical University of Denmark for providing lab facilities.

\section{References}

Ajmal, M. and A.U. Khan 1985. Effects of electroplating factory effluent on the germination and growth of hyacinth bean and mustard. Environmental Research 38: 248-255.

Bajguz, A. 2000. Blockage of heavy metals accumulation in Chlorella vulgaris cells by 24 epibrassinolide. Plant Physiolology and Biochemistry 38: 797-801.

Beker, E.W. 1986. Nutritional properties of microalgae: potentials and constraints. In Handbook of microalgal mass culture (Ed. A. Richmond). CRC press Inc. Boca Raton, Florida. pp. 339-376.

Borowitzka, M.A. and L.J. Borowitzka 1988. Microalgal Biotechnology. Cambridge University Press, Cambridge.

Clemens, S., M.G. Palmgren and U. Kramer 2002. A long way ahead: understanding and engineering plant metal accumulation. TRENDS in Plant Science 7: 309-315.

Corrin, M.L. and D.F.S. Natusch 1977. Physical and chemical characteristics of environmental lead. In Lead in the environment (Eds. W.R. Boggess and B.G. Wixson). Washington, DC. National Science Foundation. pp. 7-31.

Crist, R.H., K. Oberholder, D. Schwart, J. Marzoff and D. Ryder 1988. Interaction of metals and protons with algae. Environmental Science and Technology 22: 755-760.

De Filippis, L.F., and C.K. Pallaghy 1994. Heavy metals: Sources and biological effects. In Algae and water pollution (Eds. L.C. Rai, J.P. Gaur and C.J. Soeder). E. Schweizerbart'sche Verlagsbuchhandlung, Stuttgart. pp 31-77.

Donmez, C.C., Z. Aksu, A. Ozturk and T. Kutsal 1999. A comparative study on heavy metal biosorption characteristics of some algae. Process Biochemistry 34: 885-892.
Fernando, N.P., M.A. Healy, M. Aslam, S.S. Davis and A. Hussein 1981. Lead poisoning and traditional practices: the consequences for world health. A study in Kuwait. Public Health, 95: 250-60.

Fernando, Q. 1995. Metal speciation in environmental and biological systems. Environ. Health Perspect. Suppl. 103: 13-16.

Hamdy, A.A. 2000. Biosorption of heavy metals by marine algae. Current Microbiology 41: 232-238.

Hamer, D.H. 1986. Metallothionein. Annual Review of Biochemistry 55: 913-951.

Harrison, R.M. and D.P.H. Laxen 1980. Metals in the environment. 1. Chemistry. Chem. Br. 16: 316320

Honeyman, B.D. and P.H. Santschi 1988. Metals in aquatic systems. Environmental Science and Technology 22: 862-871.

Jin, X., C. Nalewajko and D.J. Kushner 1996b. Comparative study of nickel toxicity to growth and photosynthesis in nickel-resistant and sensitive strains of Scenedesmus acutus $f$. alternans (Chlorophyceae). Microbial Ecology 31: 103-114.

Kamnev, A.A. and V. van der Lelie 2000. Chemical and biological parameters as tools to evaluate and improve heavy metal phytoremediation. Bioscience Reports 20: 239-258.

Kaplan, D., Y.M. Heimer, A. Abeliovich and P.B. Goldbrough 1995. Cadmium toxicity and resistance in Chlorella sp. Plant Science 109: 129-137.

Kessler, E. 1986. Limits of growth of five Chlorella species in the presence of toxic heavy metals. Archive of Hydrobiology [Suppl.] 73: 123-128.

Kondo, N., K. Imai , M. Isobe, T. Goto, A. Murasugi, C. Wada-Nakagawa and Y. Hayashi 1984. Cadystin $\mathrm{A}$ and $\mathrm{B}$, major unit peptides comprising cadmium binding peptides induced in a fission yeast-separation, revision of structure and synthesis. Tetrahedron Letter 25: 3869-3872.

Kramer, U., J.D. Cotter-Howells, J.M. Charonock, A.J.M. Baker and J.A.C. Smith 1996. Free histidine as metal chelator in plants that accumulate nickel. Nature 379: 653-638.

Lopez-Suarez, C.E., J.M. Castro-Romero, M.V. Gonzalez-Rodrigue, E. Gonalez-p Soto, J. PerezIglesias, H.M. Seco-Lago and J.M FernandezSolis 2000. Study of the parameters affecting the binding of metals in solution by chlorella vulgaris. Talanta 50: 1313-1318. 
Pawan Raj Shakya and Neena Khwaounjoo (Malla) / Our Nature (2012) 10: 156-166

Macfie, S.M. and P.M. Welbourn 2000. The cell wall as a barrier to uptake of metal ions in the unicellular green alga Chlamydomonas reinhardtii (Chlorophyceae). Archive of Environmental Contamination and Toxicology 39: 413-419.

Mehta, S.K. and J.P. Gaur 1999. Heavy-metalinduced proline accumulation and its role in ameliorating metal toxicity in Chlorella vulgari. New Phytology 143: 253-259.

Prasad, M.N.V. 1995. Cadmium toxicity and tolerance in vascular plant. Environmental and Experimental Botany 35: 525-544.

Roy, D., P.N. Greenlaw and B.S. Shane 1993. Adsorption of heavy metals by green algae and ground rice hulls. Journal of Environmental Science and Health 28: 37-50.

Salt, D.E., R.D. Smith and I. Raskin 1998. Phytoremediation. Annual Review of Plant Physiology and Plant Molecular Biology 49: 643-668.

Sandau, E., P. Sandau and O. Pulz 1996. Heavy metal sorption by microalgae. Acta Biotechnology 16: 227-235.
Sil, A. and J. Chenevert 1998. EMS Mutagenesis, Hersckowitz Lab Protocol, Dept. of Biochemistry and Biophysics, University of California, San Francisco.

U.S. ATSDR 2005. Toxicological profile for lead. (Draft for Public Comment). U.S. Department of Health and Human Services. Public Health Service. Agency for Toxic Substances and Disease Registry, Atlanta, U.S.A.

Vilchez, C., I. Garbayo, M.V. Lobato and J.M. Vega 1997. Microalgae-mediated chemicals production and wastes removal. Enzyme Microbial Technology 20: 562-572.

Wang, H.K. and J.M. Wood 1984. Bioaccumulation of nickel by algae. Environmental Science and Technology 18(2): 106-109.

Wong, J.P.K., Y.S. Wong and N.F.Y. Tam 2000. Nickel biosorption by two chlorella species, $C$. Vulgaris (a commercial species) and C. Miniata (a local isolate). Bioresource Technology 73: 133-137.

Wong, P.K. and C.K.Wong 1990. Toxicity of nickel and nickel electroplating water to Chlorella pyrenoidosa. Bulletin, Environmental Contamination and Toxicology 45: 752-759. 